\title{
In Vitro Antioxidant Property of Convolvulus aucheri and Its NO Inhibitory Potential in LPS- activated NSCLC Cells
}

\author{
Cennet ÖZAY ${ }^{1 *}$
}

\begin{abstract}
Latterly, scientists have turned into progressively curious about therapeutic herbs. A lot of Convolvulus taxa display different biologic activities. In this study, we aimed to evaluate nitric oxide (NO) inhibitive effect of Convolvulus aucheri in LPS-induced non-small cell lung cancer (NSCLC) cells, such as HCC78 and H1975 and determine its antioxidant capacity. While Griess assay was applied to determine the nitrite level as an index of NO production, $\beta$-carotene/linoleic acid test was used for the determining antioxidant effect. Cytotoxic activity of $C$. aucheri extract was detected by using CellTiter-Glo assay. The extract induced a bigger cytotoxic activity on H1975 cells than the HCC78 cells and decreased NO production in concentration-dependent manner. The highest inhibitory potential against NO formation was observed to be $113.06 \mu \mathrm{M}$ nitrite at a concentration of $40 \mu \mathrm{g} / \mathrm{mL}$ in HCC78 cells. As for the antioxidant activity, C. aucheri showed the highest antioxidant activity of $70.89 \%$. These data bring to mind that $C$. aucheri may be a useful source for exploration new anticancer compounds.
\end{abstract}

Keywords: Convolvulaceae, C. aucheri extract, lipopolysaccharide, lung cancer, NO assay

\section{Convolvulus aucheri'nin In vitro Antioksidan Özelliği ve LPS-aktif NSCLC Hücrelerinde NO Engelleyici Potansiyeli}

ÖZET: Son zamanlarda, bilim adamları tedavi edici bitkiler hakkında giderek daha fazla ilgili hale geldiler. Birçok Convolvulus taksonu farklı biyolojik aktiviteler göstermektedir. Bu çalışmada, Convolvulus aucheri'nin LPS ile uyarılmış HCC78 ve H1975 gibi küçük hücre dış1 akciğer kanseri (KHDAK) hücrelerinde nitrik oksidi (NO) inhibe edici etkisini değerlendirmeyi ve antioksidan kapasitesini belirlemeyi amaçladık. NO üretiminin bir göstergesi olan nitrit düzeyini belirlemek için Griess testi uygulanırken, antioksidan etkinin belirlenmesi için ise $\beta$-karoten/linoleik asit testi kullanıldı. C. aucheri ekstraktının sitotoksik aktivitesi, CellTiter-Glo deneyi kullanılarak tespit edildi. Ekstrakt H1975 hücrelerinde HCC78 hücrelerinden daha büyük bir sitotoksik aktiviteye sebep olmuştur ve NO üretimini konsantrasyona bağlı olarak azaltmıştır. NO oluşumuna karşı en yüksek inhibitör potansiyelin, HCC78 hücrelerinde $40 \mu \mathrm{g} / \mathrm{mL}$ konsantrasyonda $113.06 \mu \mathrm{M}$ nitrit olduğu gözlenmiştir. Antioksidan aktiviteye gelince, C. aucheri en yüksek antioksidan aktivitesini \%70.89 ile göstermiştir. Bu veriler, C. aucheri'nin yeni antikanser bileşiklerinin araştırılması için yararlı bir kaynak olabileceğini akla getirmektedir.

Anahtar Kelimeler: Convolvulaceae, $C$. aucheri ekstrakt1, lipopolisakkarit, akciğer kanseri, NO testi

\footnotetext{
${ }^{1}$ Cennet ÖZAY (Orcid ID: 0000-0002-1120-6122), Pamukkale Üniversitesi, Fen Edebiyat Fakültesi, Biyoloji Bölümü, Denizli, Türkiye

*Sorumlu Yazar / Corresponding Author: Cennet ÖZAY, e-mail: cennetozay@ hotmail.com

Geliş tarihi / Received:09.03.2019

Kabul tarihi / Accepted:15.05.2019
} 


\section{INTRODUCTION}

Since ancient times, plants have been utilized by humans for remedial goals and have shaped the source of a lot of medications used in modern eras. The bioactive compounds obtained from plants have used in medicine for different curative cares since old times (Schmidt et al., 2008; Mammadov, 2014). A wide range of significant plants from Convolvulaceae family have been utilized for curing lots of disorders with regard to their secondary metabolites (Jacobs and NRCS, 2007). Alkaloids, flavonoids, coumarins, sterols, saponins, resin glycosides, tannins and stilbene derivatives have been isolated from plants of the genus Convolvulus L. (Noda et al., 1990; Todd et al., 1995; Menemen et al., 2002).

The genus Convolvulus L. belongs to Convolvulaceae family, including 250 taxa, generally recognized as bindweeds. With respect to recent researches, this genus is represented with 35 species in Turkey (Güner et al., 2012). Extracts of various members of Convolvulus have been demonstrated to have antioxidant, anticancer and antinociceptive activities (Rachitha et al., 2018; Atta and El-Sooud, 2004; Sadeghi-Aliabadi et al., 2008).

The free radical nitric oxide is include in numerous physiological mechanisms such as antimicrobial, anticonvulsant and anticancer activities (Nakagawa and Yokozawa, 2002). However, excessive and unregulated NO synthesis possibly facilitate tumour growth and dissemination in many human cancers (Choudhari et al., 2013). For this reason, there is a need for the improving of novel medications as powerful inhibitors of NO generation in connection with the cure for cancer.

Antioxidants convert reactive oxygen species to non-toxic products and stop or eliminate the side effects of reactive oxygen species, prevent some disorders, such as cancer, cardiovascular diseases, diabetes, infections and ischemia (Al-Dabbas, 2017). As it is known, several biological activity tests such as antioxidant, antimicrobial and anticancer assays reveal the biological potential of various plants. For that reason, we determined the antioxidant and antiproliferative activity of Convolvulus aucheri Choisy and also its NO inhibitory potential in lipopolysaccharide (LPS) stimulated NSCLC cells.

\section{MATERIAL AND METHODS}

\section{Plant material and extraction}

The individuals of Convolvulus aucheri Choisy were collected from Hatay: NATO Radar Station in Kisecik, serpentine slopes, Turkey, ca $880 \mathrm{~m}$, June 2009. The voucher specimen was deposited at the Akdeniz University Herbarium (Voucher no: C. Aykurt 2665). The plants were air-dried and their aerial parts were powderized. Methanol, ethanol, acetone and petroleum benzine were used for the extraction in a shaker water bath for 6 hours at $55^{\circ} \mathrm{C}$ (Ozay et al., 2015). The extracts were filtered and vaporized by using rotary evaporator and then lyophilized. The crude extracts were kept at $+4^{\circ} \mathrm{C}$ until needed.

\section{$\beta$-carotene/linoleic acid test}

Antioxidant activity of the extracts was detected according to the method of inhibiting linoleic acid oxidation (Sokmen et al., 2004). BHT (an artificial antioxidant) was utilized as positive control.

\section{Cytotoxicity assay}

H1975 and HCC78 cells were used as human non-small cell lung cancer cell lines and cultured in RPMI 1640 medium in a $\mathrm{CO}_{2}$ incubator. 24 hours incubation after seeding into 96-well plates $\left(2 \times 10^{3}\right.$ cells/well), the medium was removed from the well leaving the adherent cells and cells were applied with extracts for 72 hours in the range of $0.625-40 \mu \mathrm{g} / \mathrm{mL}$. After time was up cytotoxicity was determined by using CellTiter-Glo assay. Viability was 
calculated using the background-corrected absorbance as follows:

Viability $(\%)=$ Abs of experiment well $/$ Abs of control well x 100

\section{Nitric oxide assay}

After 24 hours preincubation of H1975 and HCC78 cells with lipopolysaccharide $(1 \mu \mathrm{g} / \mathrm{mL})$, the extracts $(0.625-40 \mu \mathrm{g} / \mathrm{mL})$ were put in and incubated for 48hours (Yang et al., 2009). Nitrite, as an indicator of NO production in the medium, was determined via Griess reagent. After mixing the supernatant with the reagent in equal amounts, it was allowed to incubate for 10 minutes. And then using a microplate reader, absorbances were measured at 560 nanometre.

\section{Statistical analysis}

Statistical analysis was performed using the software SPSS version 22.0 program. Statistical significance was determined using the one-way ANOVA. Multiple group comparisons were analyzed with Tukey's multiple comparison test. Data were expressed as a mean \pm SD. $p$ value of $<0.05$ was considered to be statistically significant.

\section{RESULT AND DISCUSSION}

\section{Antioxidant activity}

Different solvent extracts of $C$. aucheri were used so as to analysed antioxidant activity via $\beta$-carotene-linoleic acid test. Linoleic acid oxidation was prevented excellently by antioxidants (Tepe et al., 2007). The outcomes of the antioxidant activity of $C$. aucheri were tabulated in Table 1. Among all the extracts, ethanolic extract showed the highest antioxidant activity $(70.89 \pm 0.09 \%)$ while petroleum benzine extract showed the lowest activity $(42.43 \pm 0.04 \%)(p<0.05)$. The reason of the same plant's extracts showing different antioxidant activity may be due to the polarities of the solvents. None of the tested extracts exceed BHT antioxidant efficiency. Extracts of various members of this genus, such as $C$. arvensis (Krzaczek et al., 2004), C. pluricaulis (Vijayakumar et al., 2005), C. hystrix (El-Askary et al., 2006), C. althaeoides (Tawaha et al., 2007) and C. fatmensis (Atta et al., 2007) have been reported to show antioxidant activity.

The use of only one method does not reflect the antioxidant activity of plant extracts due to complicated structure of bioactive secondary metabolites (Du et al., 2009). In a previous study, DPPH free radical cleaning power of $C$. aucheri was reported as $59.50 \%$ (Cengiz et al., 2015). Several literatures also informed that DPPH scavenging power of Convolvulus species such as C. arvensis (Elzaawely and Tawata, 2012) and $C$. dorycnium (Nacef et al., 2010). In a preliminary study, Thrakal et al. (2010) reported the antioxidant activity of $C$. arvensis extract using the DPPH method, nitric oxide scavenging activity and the reducing power assay.

Table 1: Antioxidant power of $C$. aucheri

\begin{tabular}{cc}
\hline Extracts & $\begin{array}{c}\boldsymbol{\beta} \text {-carotene linoleic acid assay } \\
(\boldsymbol{\%})\end{array}$ \\
\hline Ethanol & $70.89 \pm 0.09^{\mathrm{a}}$ \\
Methanol & $66.43 \pm 0.07^{\mathrm{a}}$ \\
Acetone & $45.43 \pm 0.05^{\mathrm{b}}$ \\
Petroleum benzine & $42.43 \pm 0.04^{\mathrm{b}}$ \\
BHT & $95.64 \pm 0.12^{\mathrm{c}}$ \\
\hline Values expressed are means \pm SD, Different letters indicate significant difference $(p<0.05)$.
\end{tabular}




\section{Cytotoxic activity}

Because of ethanol extract has higher antioxidant power than others, ethanol extracts were used in CellTiter-Glo assay for cell viability and nitric oxide assay. To evaluate the antiproliferative activity of the $C$. aucheri ethanol extract against H1975 and HCC78 cells, CellTiter-Glo assay was carried out. Decrease in viability in H1975 and HCC78 were observed in a concentration-dependent manner $(p<0.05)$ (Fig. 1). Cytotoxic potential of $C$. aucheri on H1975 cells was observed to be more effective than HCC78. The percent of cell viability of H1975 and HCC78 cells was determined as $56.92 \%$ and $61.23 \%$ respectively at a concentration of $40 \mu \mathrm{g} / \mathrm{mL}$.
Lung cancer is one of the deadliest cancers for human being. Non-small cell lung cancer (NSCLC) accounts for the majority of (85\%) whole lung cancers (Zappa and Mousa, 2016). Plant origin products show hopeful resources of antitumor substances with lower adverse effect as compared to synthetic medications. In a previous study, where researchers demonstrated that different solvent extracts of $C$. arvensis had superior cytotoxic potential on HeLa cells (Sadeghi-Aliabadi et al., 2008). In another study researchers showed that the ubiquitous $C$. arvensis extract could be considered as a promising anti-cancer agent, with over 50\% inhibition of tumor growth activity at non-toxic doses (Meng et al., 2002).

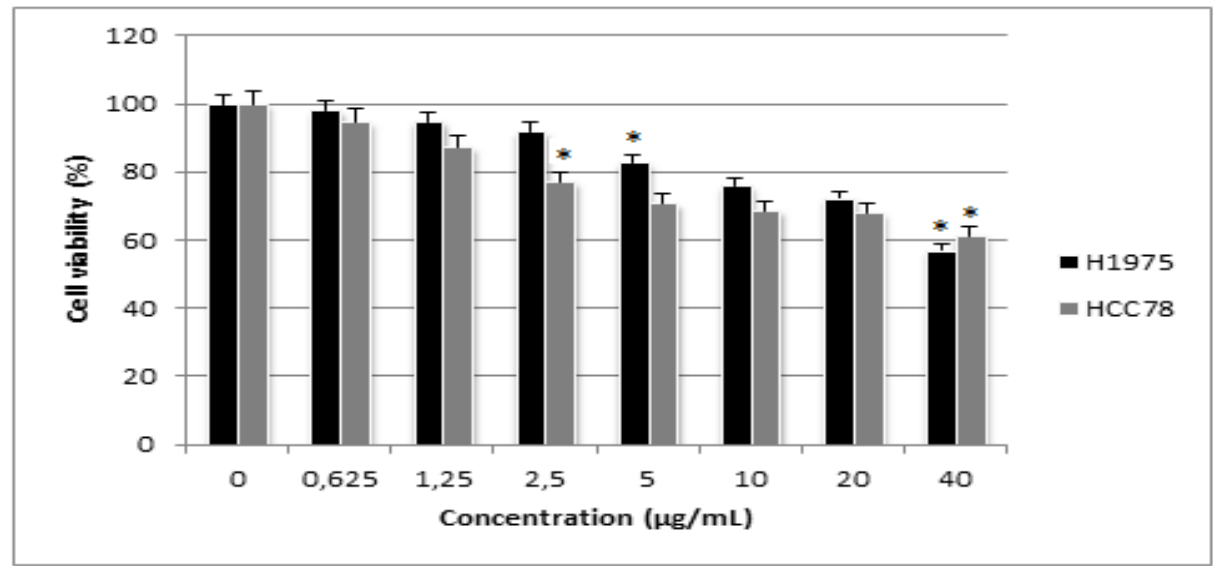

Figure 1: Cell viability of $C$. aucheri on H1975 and HCC78 cells proliferation. Data are presented as mean \pm SD. ${ }^{*} p<0.05$.

\section{Nitric oxide inhibitory activity}

It is indicated that diverse regulating reactions to different NO levels have been viewed in various types of cancers. In general, at low concentrations of nitric oxide are considered to stimulate the growth of tumors. Nitric oxide acts as a powerful anticancer agent by stimulating apoptosis and necrosis in too high concentrations. While increase in nitric oxide synthase production is anticipated to indicate anticancer effect, it has been showed that nitric oxide may rise the proliferation and progress of cancer because of the impacts on metastasis process (Derici and Demirel-Y1lmaz, 2017).
In this study, ethanolic extract obtained from $C$. aucheri was investigated for its effects on the LPS-activated NO production in H1975 and HCC78 cells. Nitric oxide generation was determined as nitrite concentration in the supernatant. The nitrite accumulation in the cells decreased due to the rising extract concentration ( $p<0.05$ ). Nitrite levels of H1975 and HCC78 cells ranged from 145.10 to 240.55 and 113.06 to $250.32 \mu \mathrm{M}$, respectively. Nitric oxide inhibitory activity of $C$. aucheri extract in LPSstimulated cells was shown in Figure 2 and 3. 


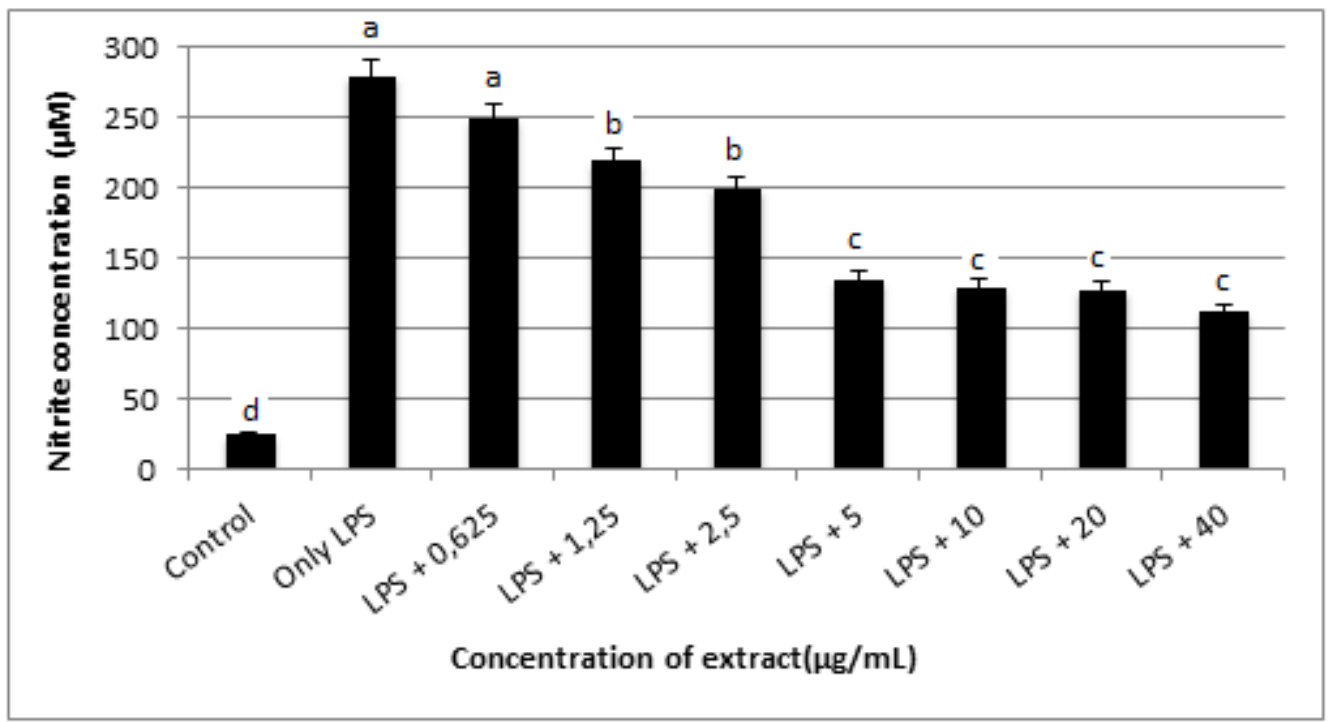

Figure 2: Nitric oxide inhibitory activity of $C$. aucheri in LPS-stimulated HCC78 cells. Data are presented as mean \pm SD. Different letters indicate significant difference $(p<0.05)$.

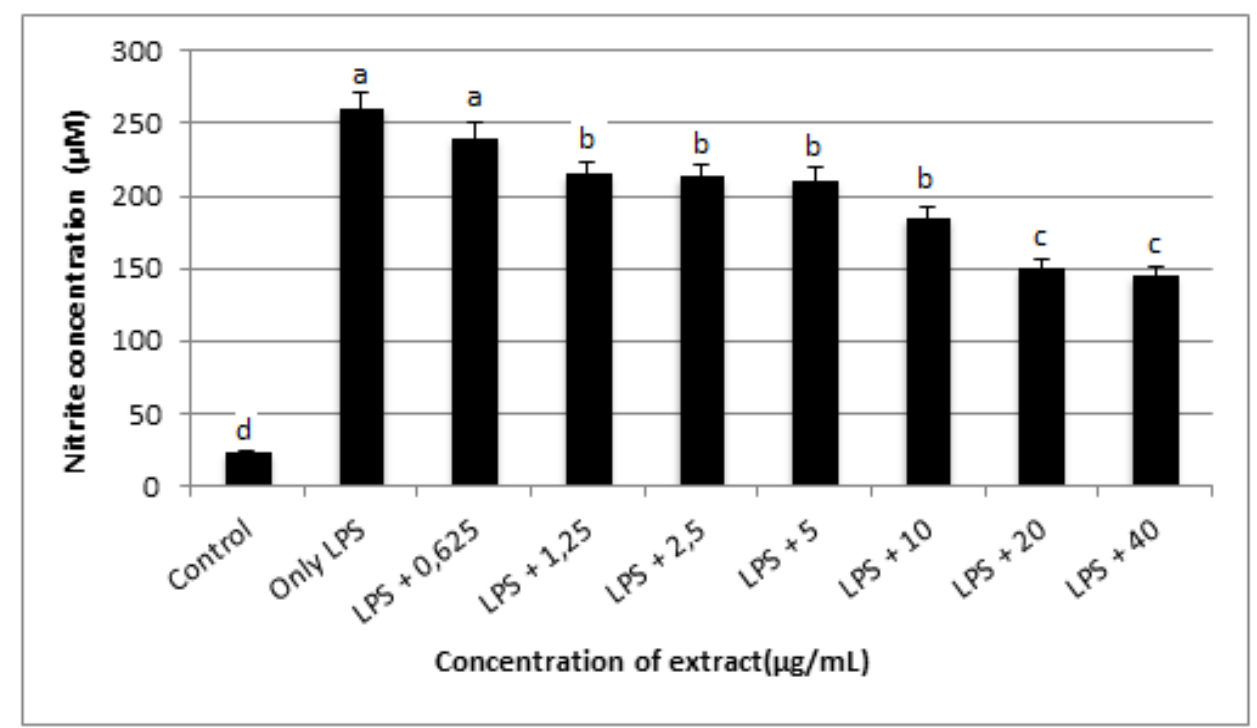

Figure 3: Nitric oxide inhibitory activity of $C$. aucheri in LPS-stimulated H1975 cells. Data are presented as mean \pm SD. Different letters indicate significant difference $(p<0.05)$.

Recent researches have pointed out the working principles in back of the action of natural antioxidants on the prevention of nitric oxide generation (Al Dhaheri et al., 2013). Plants are rich in bioactive molecules acted as natural antioxidants, such as phenolic compounds, alkaloids, terpenes, saponins and glycosides. Hence, prominent interest has been concentrated on the use of natural antioxidants to prevent nitric oxide generation (Yen et al., 2008; Mohsen and Ammar, 2009).

\section{CONCLUSION}

In conclusion, we demonstrated that $C$. aucheri ethanolic extract, which has antioxidant activity, reduces nitric oxide production in H1975 and HCC78 cells. These findings imply that ethanol extracts obtained from $C$. aucheri deserve better examination so as to identify its phytocompounds with NO inhibitory potentials. 


\section{ACKNOWLEDGEMENTS}

I would like to thank the senior taxonomist Dr. Candan Aykurt, in Department of Biology, Akdeniz University, for the collection and identification of the plant. I would also like to thank the Cancer Research Center, Pamukkale University, for graciously providing NSCLC cells and I thank in particular, senior biologist Ege Riza Karagür, for his support. I am also immensely grateful to Prof. Dr. Ramazan Mammadov, in Department of Biology, Pamukkale University, for sharing his wisdom and advice.

\section{REFERENCES}

Al-Dabbas MM, 2017. Antioxdant activity of different extracts from the aerial part of Moringa peregrina (Forssk.) Fiori, from Jordan. Pakistan Journal of Pharmaceutical Sciences, 30(6): 2151-2157.

Al Dhaheri Y, Attoub S, Arafat K, AbuQamar S, Viallet J, et al., 2013. Anti-Metastatic and Anti-Tumor Growth Effects of Origanum majorana on Highly Metastatic Human Breast Cancer Cells: Inhibition of NFkB Signaling and Reduction of Nitric Oxide Production. PLoS ONE, 8(7): e68808.

Atta AH, El-Sooud KA, 2004. Antinociceptive effect of some Egyptian medicinal plant extracts. Journal of Ethnopharmacology, 95: 235-238.

Atta AH, Mohamed NH, Nasr SM, Mouneir SM, 2007. Phytochemical and pharmacological studies on Convolvulus fatmensis Ktze. Journal of Natural Remedies, 7: 109-119.

Cengiz S, Mammadov R, Aykurt C, Tasdelen G, 2015. Variations in antioxidant enzyme levels of rats exposed to ethanol extracts of Convolvulus species. Industrial Crops and Products, 74: 304-308.

Choudhari SK, Chaudhary M, Bagde S, Gadbail AR, Joshi V, 2013. Nitric oxide and cancer: a review. World Journal of Surgical Oncology, 11: 118.
Derici MK, Demirel-Y1lmaz E, 2017. Nitrik oksitin kanser gelişimi ve metastaz üzerine etkileri. Türk Hijyen ve Deneysel Biyoloji Dergisi, 74(2): 161-174.

Du GR, Li MJ, Ma FW, Liang D, 2009. Antioxidant capacity and the relationship with polyphenol and Vitamin $\mathrm{C}$ in Actinidia fruits. Food Chemistry, 113: 557-562.

El-Askary HI, Abou-Hussein DR, Shehab NG, Sleem AA, 2006. Bioactive caffeoylquinic acid derivatives from Convolvulus hystrix Vahl. Bulletin of Faculty of Pharmacy, Cairo University, 44: 127-134.

Elzaawely AA, Tawata S, 2012. Antioxidant activity of phenolic Rich Fraction Obtained from Convolvulus arvensis L. leaves grown in Egypt. Asian Journal of Crop Science, 4(1): 19.

Güner A, Aslan S, Ekim T, Vural M, Babaç MT, 2012. Türkiye Bitkileri Listesi (Damarlı Bitkiler). İstanbul, Turkey: Flora Araştırmaları Derneği ve Nezahat Gökyiğit Botanik Bahçesi Yayını (in Turkish).

Jacobs J, NRCS, 2007. Invasive Species Specialist, Ecology and management of field bindweed [Convolvulus arvensis L.] Natural resources conservation service Invasive species. Technical Note No., MT-9, 1-9.

Krzaczek T, Bogucka-Kocka A, Ryn D, 2004. Chromatographical analysis of phenolic compounds in herb Convolvulus arvensis $\mathrm{L}$. Herba Polonica, 50: 17-22.

Mammadov R, 2014. Secondary Metabolites in Spermatophyta. 428 pp., Nobel Press, Ankara, Turkey (in Turkish).

Menemen Y, Williams CA, Jury SL, 2002. Flavonoid patterns in Convolvulus L. (Convolvulaceae) species from Morocco. Pakistan Journal of Botany, 34: 291-295.

Meng XL, Riordan NH, Casciari JJ, Zhu Y, Gonzalez JM, Miranda-Massari JR, Riordan HD, 2002. Effect of High Molecular Mass Convolvulus arvensis Extract on Tumor Growth and Angiogenesis. Pharmacognosis, 21: 323-328.

Mohsen SM, Ammar ASM, 2009. Total phenolic contents and antioxidant activity of corn tassel extracts. Food Chemistry, 112: 595-598. 
Nacef S, Jannet HB, Abreu P, Mighri Z, 2010. Phenolic constituents of Convolvulus dorycnium flowers. Phytochemistry Letters, 3 : 66-69.

Nakagawa T, Yokozawa T, 2002. Direct scavenging of nitric oxide by green tea. Food and Chemical Toxicology, 40: 1745-1750.

Noda N, Kogetsu H, Kawasaki T, Miyahara K, 1990. Scammonins I and II, the resin glycosides of radix Scammoniae from Convolvulus scammonia. Phytochemistry, 29: 3565- 3569.

Ozay C, Mammadov R, Tasdelen G, Karagur ER, Akca H, 2015. Potential antioxidant, antiproliferative and hepatoprotective effects of Crataegus meyeri. Journal of Food Biochemistry, 39: 548-553.

Rachitha P, Krupashree K, Jayashree GV, Kandikattu HK, Amruta N, Gopalan N, Rao MK, Khanum F, 2018. Chemical composition, antioxidant potential, macromolecule damage and neuroprotective activity of Convolvulus pluricaulis. Journal of Traditional and Complementary Medicine, 8: 483-496.

Sadeghi-Aliabadi H, Ghasemi N, Kohi M, 2008. Cytotoxic effect of Convolvulus arvensis extracts on human cancerous cell line. Research in Pharmaceutical Sciences, 3(1): 3134.

Schmidt B, Ribnicky DM, Poulev A, Logendra S, Cefalu WT, Raskin I, 2008. A natural history of botanical therapeutics. Metabolism, 57 (Suppl 1): S3-9.

Sokmen A, Gulluce M, Akpulat HA, Daferera D, Tepe B, Polissiou M, Sokmen M, Sahin F, 2004. The in vitro antimicrobial and antioxidant activities of the essential oils and methanol extracts of endemic Thymus spathulifolius. Food Control, 15(8): 627-634.

Tepe B, Daferera D, Tepe AS, Polissiou M, Sokmen A, 2007. Antioxidant activity of the essential oil and various extracts of Nepeta flavida Hub.-Mor. from Turkey. Food Chemistry, 103: 1358-1364.
Tawaha K, Alali FQ, Gharaibeh M, Mohammad M, El-Elimat T, 2007. Antioxidant activity and total phenolic content of selected Jordanian plant species. Food Chemistry, 104: 13721378.

Thakral J, Borar S, Kalia AN, 2010. Antioxidant Potential Fractionation from Methanol Extract of Aerial Parts of Convolvulus arvensis Linn (Convolvulaceae). International Journal of Pharmaceutical Sciences and Drug Research, 2: 219-223.

Todd FG, Stermitz FR, Schultheis P, Knight AP, Traub-Dargatz J, 1995. Tropane alkaloids and toxicity of Convolvulus arvensis. Phytochemistry, 39: 301-303.

Vijayakumar M, Govindarajan R, Singh DP, Rawat AKS, 2005. Review of some important plants with antioxidant and other biological activities. Pharmacognosy Magazine, 1: 129-135.

Yang EJ, Yim EY, Song G, Kim GO, Hyun CG, 2009. Inhibition of nitric oxide production in lipopolysaccharide-activated RAW 264.7 macrophages by Jeju plant extracts. Interdisciplinary Toxicology, 2(4): 245-249.

Yen GC, Duh PD, Huang DW, Hsu CL, Fu TYC, 2008. Protective effect of pine (Pinus morrisonicola Hay.) needle on LDL oxidation and its anti-inflammatory action by modulation of iNOS and COX-2 expression in LPSstimulated RAW 264.7 macrophages. Food and Chemical Toxicology, 46: 175-185.

Zappa C, Mousa SA, 2016. Non-small cell lung cancer: current treatment and future advances. Translational lung cancer research, 5(3): 288-300. 